\title{
Does one report design suit all sorts of readers in the forest sector?
}

\author{
Christoph Hartebrodt ${ }^{(1)}$, Kathryn Howard ${ }^{(2)}$ \\ (1) Forstliche Versuchs- und Forschungsanstalt Baden-Württemberg. Wonnhaldestrasse, 4. 79100 Freiburg (Germany). \\ E-mail: christoph.hartebrodt@forst.bwl.de \\ (2) The University of Auckland. Private Bag 92019. Auckland 1142 (New Zealand).
}

Received 19 July 2016, accepted 2 August 2017, available online 13 october 2017.

This article is distributed under the terms and conditions of the CC-BY License (http://creativecommons.org/licenses/by/4.0)

Description of the subject. In the past two decades, new types of reports, such as sustainability reports, have become more important. Normally, issuing reports is a cost-intensive activity; however, the effectivity in terms of communicational success is often unknown. Research about forest reporting has often focused on general acceptance of different reporting concepts. Analysis about the perception of published reports is either uncommon or results may not be published for several internal reasons.

Objectives. This double case study aims to identify if conceptual elements of sustainability reporting (SR) meet the expectations of different target groups of public forest enterprises in two German provinces.

Method. A three sphere model derived from communication theory is introduced and used to analyze the success of reports in different stakeholder groups. A set of hypotheses is derived from the state of knowledge on sustainability as well as corporate social responsibility reporting and is structured according to the model. The hypotheses are tested on the basis of a double case study.

Results. It can be shown that satisfaction with traditional reports is already high; however, structural components of SR are also accepted. Readers want shorter reports and printed versions. Results indicate that the SR concept can be transferred to the readers of forest reports. Differences between stakeholder groups are mainly related to contents and different means of verification.

Conclusions. The concept of SR can be basically applied in forest enterprises and meets the expectations of most readers. However, it must be kept in mind that traditional reporting concepts already meet most of the expectations of the relevant target groups. Any effort to implement a new reporting instrument should be supported by an ex ante evaluation of the expectations of the target readership.

Keywords. Reports, information transfer, stakeholders, Germany.

Y a-t-il un « format unique » de rapports de développement durable adapté à tous les lecteurs dans le secteur forestier ? Description du sujet. Au cours des deux dernières décennies, de nouveaux types de rapports, tels que les rapports de développement durable, ont gagné en importance. La publication de ce type de documents est en général couteuse, pourtant il est difficile de savoir dans quelle mesure l'objectif principal, qui est la communication, est toujours atteint. Normalement, la recherche sur les rapports dans le secteur forestier se focalise sur l'acceptation générale de différents concepts de couverture médiatique. L'analyse de la perception du rapport lui-même n'est pas habituelle ou les résultats ne sont pas publiés pour plusieurs raisons internes.

Objectifs. L'étude vise à vérifier si le concept des rapports de développement durable répond aux attentes variées des lecteurs ciblés des entreprises forestières publiques dans deux états de l'Allemagne.

Méthode. Un modèle à trois sphères, dérivé de la théorie de la communication, est introduit et utilisé pour l'analyse du succès des rapports dans les différents groupes participants. Un ensemble d'hypothèses est dérivé de l'état de l'art sur le développement durable, notamment des rapports de responsabilité sociale des entreprises, et structuré selon le modèle. Ensuite, les hypothèses sont testées sur la base d'une étude en double cas.

Résultats. On peut montrer que la satisfaction des lecteurs à l'égard des rapports traditionnels actuels est déjà élevée. De même, les composantes structurelles des rapports sur le développent durable (Sustainability Reporting [SR]) sont bien acceptées. Les lecteurs souhaitent des rapports plus courts et en version imprimée. Les résultats montrent que le concept du SR peut être 
transféré aux lecteurs des rapports du secteur forestier. Les différences entre les groupes-cibles sont principalement liées au contenu et aux différentes technologies d'assurance.

Conclusions. Le concept de rapports sur le développement durable peut être appliqué dans les entreprises forestières et répond aux attentes de la plupart des lecteurs. Cependant, il faut garder à l'esprit que les concepts traditionnels des rapports couvrent déjà la plupart des attentes des groupes-cibles les plus importants. Tout effort sur la mise en œuvre d'un nouveau type de rapport devrait être basé sur une évaluation ex ante des attentes du public cible.

Mots-clés. Rapport, transfert de l'information, partie intéressée, Allemagne.

\section{INTRODUCTION}

New types of reporting instruments, which go beyond pure financial reporting, are growing in importance. These forms of reporting arose after the Rio Summit in the 1990s from the merging of reporting instruments developed for the corporate social responsibility and environmental movements (Gebauer et al., 2007).

Forest reporting has a long tradition, which historically focused on financial and silvicultural matters. First attempts to establish reports on social issues took place in the 1970s (Kenk, 1975) and, starting in the 1980s, more ecological topics were addressed. To date, German state forestry enterprises disclose performance information in a wide variety of reporting formats. The majority of forestry sector reports still follow traditional business reporting structures (Hartebrodt et al., 2009a).

Enterprises spend a considerable amount of money on reporting. In larger stock companies, direct costs for one annual report can reach up to 100,000 EUR (Gruda, 2016). Together with the work time, the cost can easily reach half a million Euros or more (Thurm, 2013; Wendler, 2015). Nevertheless, it is notable that almost no literature evaluating the success of individual reporting activities exists to date. When publishers do not adopt a basic scepticism about the success of reporting (Hartebrodt et al., 2009a), new forms and designs of reports are frequently introduced without detailed insight into stakeholder opinions on existing or former reports and current stakeholder requirements.

Four central questions guided the research project and ultimately led to an improved contextualization of Sustainability Reporting (SR) in the forest sector:

- do existing forest reports already reflect general findings on SR?

- is SR applicable in the forest sector within the German-speaking region and does it meet the requirements of forest stakeholders?

- is it possible to satisfy the interests of various forest stakeholder groups with one report?

- are there regional differences with regard to reporting contents and reporting formats?

As a key objective of the study was to ascertain the applicability and suitability of SR in the forest sector, the formulation of hypotheses from general previous findings and crosschecking with empirical findings gathered in the forest sector was an appropriate method. Therefore, the paper is structured as follows. The state of knowledge, which includes the formulation of hypotheses and the derivation of main research topics for the empirical study, is discussed first. Materials and methods of the double case study are described in the next section, followed by a presentation of the main findings. These results are discussed in light of the related hypotheses. Finally, conclusions and an outlook are presented.

\section{STATE OF KNOWLEDGE AND FORMULATION OF GUIDING HYPOTHESES}

\subsection{Communication theories as methodological framework}

The application of communication theories leads to a wider understanding of reporting. The former prevailing focus on the report as a medium that disseminates information to recipients is gradually being replaced by an understanding of reporting as a two-way communication process (Bentele et al., 1996). Based on the findings of Küpper (2004), the factors influencing the success of a report can be structured in a framework divided into an information and outcome layer with three spheres of influencing factors (Figure 1). The different influencing spheres, which are:

- sender-related,

- recipient-related,

- report-related factors,

are used to structure the research together with issues related to reporting practice and reader satisfaction.

\subsection{Research perspectives on reporting}

The assessment of reports can focus on different aspects and can be undertaken from different perspectives. Reporting in general or different report types or reporting strategies are often examined. As shown in table 1, this type of research is the most frequent. The assessment of individual reports is, on the contrary, 
Information-Layer

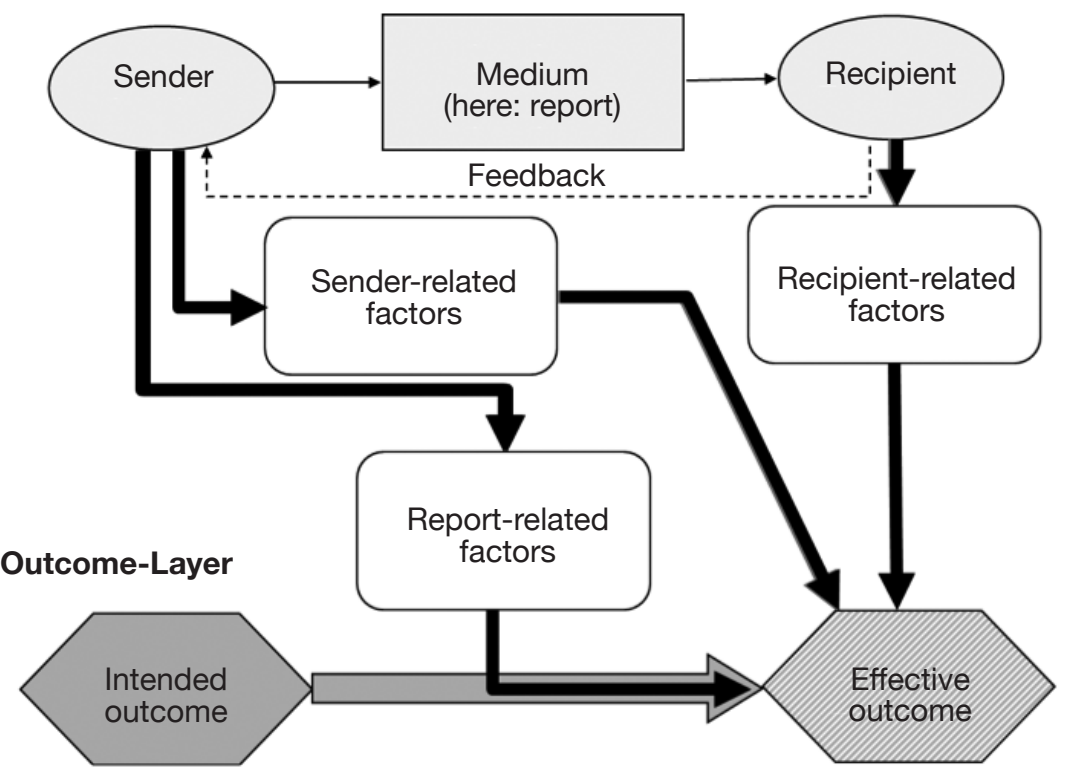

Figure 1. Influencing factors of forest reporting - Facteurs influençant les rapports concernant les forêts. assessment of reporting strategies and types of reporting has been the most frequent kind of study, whereas the assessment of published reports by their readers is less common.

\subsection{Reporting practices and reader satisfaction}

Earlier studies assessed general trends of reporting and stakeholder expectations on an abstract level. Trends hint towards the adoption of new forms of reporting. Forty-three per cent of the world's 100 largest forest sector companies in 19 countries (Kolk et al., 2002) and $61 \%$ of the world's 100 largest forest, paper, and packaging companies ${ }^{1}$ (PricewaterhouseCoopers, 2007) publish a non-financial or sustainability report. Within the German-speaking region only $20 \%$ of forestry enterprises publish a sustainability report (SRep) (Hartebrodt et al., 2009b).

In light of the fact that SR can be seen less frequent or at least not published. Secondly, the assessment can be conducted either by reporting experts or scientists or, alternatively, perceptions of the reports amongst the target readership may be of special interest. Table 1 gives an overview of the former research emphasis. It can be shown that expert as an ongoing trend internationally, our first hypothesis is as follows:

${ }^{1}$ Determined by PricewaterhouseCoopers on the basis of net sales revenue.

Table 1. Research focus and perspectives on reporting - Aspects de recherche et perspectives sur les rapports.

\begin{tabular}{lll}
\hline Research perspectives & Research focus : types of reporting & \\
\cline { 2 - 3 } & Reporting strategies & Individual report \\
\hline Expert evaluation & (1) Gebauer et al., 2011 & (1) IÖW/future, 2012 \\
& (2) Global Reporting Initiative, 2011 & (2) Kindler, 2015 \\
& (3) Clausen \& Loew, 2005 & (3) Petereit, 2008 \\
& (4) Ernst \& Young LLP, 2016 & (4) SustainAbility Ltd, 2006 \\
& (5) Gebauer \& Glahe, 2011 & (5) Harmoni, 2013 \\
& (6) Kolk, 2004 & \\
\hline Target readership Wensen et al., 2010 & (1,2) Hartebrodt et al., 2009a and 2009b & (1) Loew, 2005 \\
& (3) PKK, 2005 & (2) ACCSR, 2012 \\
& (4) Bradford et al., 2014 & (3) Evaluation Waldbericht \\
& (5) Tilt, 2007 & Schweiz, 2005 \\
& (6) Akzente Kommunikation und Beratung Gmbh und & \\
(7) Bellantuono et al., 2016 & \\
(8) Bartels et al., 2008 & \\
\hline
\end{tabular}


SR, with its structural components (e.g. stakeholder involvement, multidimensionality, use of verification techniques), is basically transferable to the German forest sector.

(Hypothesis 1)

In a worldwide study in which about one third of the total sample was from the German speaking region, reader satisfaction varied with $75 \%$ stating they were satisfied with environmental reporting, $61 \%$ with economic reporting, and $55 \%$ with social performance reporting (PKK, 2005). Deficiencies have been found in the overall quality, scope, and relevance of many SReps. Moreover, inadequacies in the setting of performance objectives, particularly social performance indicators, and in discussing challenges have been identified (O'Dwyer et al., 2005; Gebauer et al., 2007).

Based on these underlying inadequacies, our second hypothesis states:

Stakeholders dislike current reports and see inadequacies in reporting as well as imbalances across different dimensions.

(Hypothesis 2)

\subsection{Spheres of influencing factors}

General trends in reporting have been the subject of a number of studies. All of these studies have considered spheres of influencing factors and there is a wide, but not complete, overlap in the research topics included. Table 2 shows these spheres together with relevant individual success factors and related literature.

In most cases, these studies remained on an abstract level and were not related to specific existing reports. One exception is the biannual ranking of SReps of large and small to medium-sized enterprises in Germany (Gebauer et al., 2010). However, it should be mentioned that this evaluation does not include stakeholders' or readers' opinions.

Sender-related factors. Interdependencies between the perception of the publishing institution and the reception of the report have been described from a generalizing perspective in the context of communication theory (Küpper, 2004). In this study, a decision was made to exclude sender-related factors given that one forest administration was going to be restructured during the investigation period and the image of the sender was therefore deemed to be unstable.

Recipient-related factors. Hartebrodt et al. (2009a) found that forestry reports were most often read by employees and sector members. As a consequence, German forestry enterprises were addressing those readers' interests and not those of wider society. It

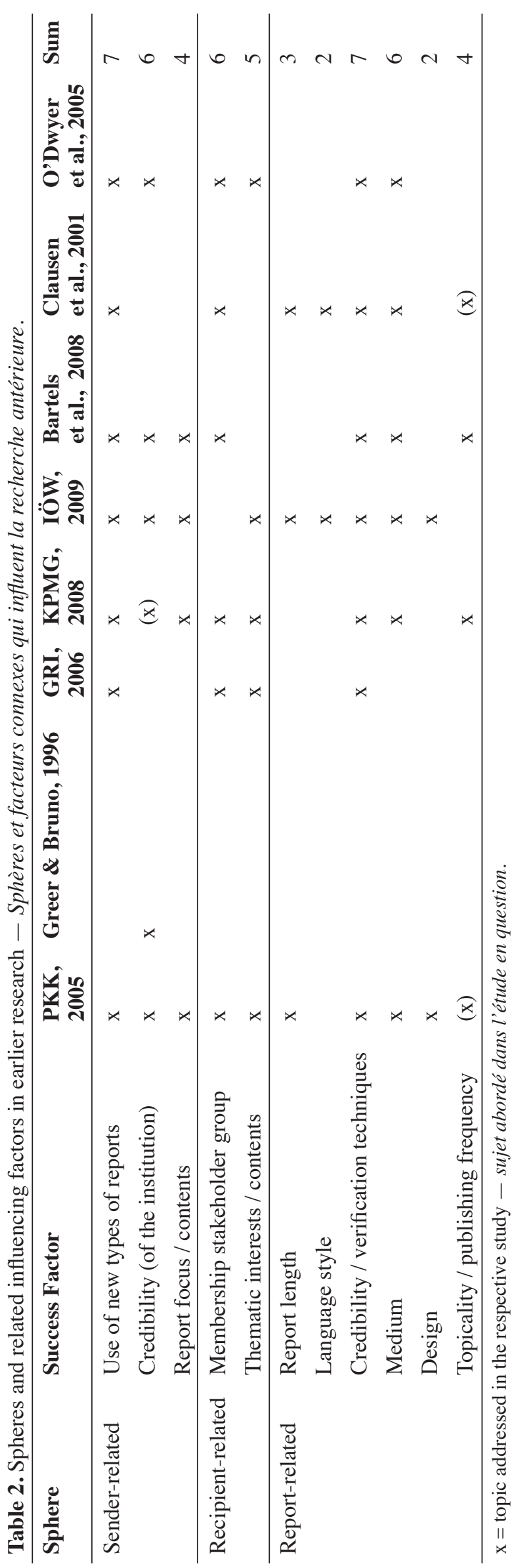


has frequently been claimed that the needs of all stakeholders cannot possibly be met in a single report (PKK, 2005). Employee matters appear as the most important social performance indicator in forestry sector reports. Of the reports produced by the world's 100 largest forest, paper, and packaging companies, $67 \%$ reported on health and safety, $56 \%$ on workforce characteristics, and $52 \%$ on training (PricewaterhouseCoopers, 2007). Readers considered the most important topics to be human rights and health and safety issues in the social sphere, corporate governance, bribery, and corruption in the economic sphere, and energy efficiency in the environmental domain (PKK, 2005). Parviainen (2008) found a national forest SRep was only used by officials and scientists and that reports with simpler messages and fewer indicators were needed for other stakeholders such as the public and policy makers.

Contrary to this, Bartels et al. (2008) did not find any substantial differences between stakeholder groups. Also, KPMG (2008) found small differences between stakeholder groups.

In light of the fact that the majority of authors found differences between stakeholders we formulated two further hypotheses:

Stakeholder groups are interested in different topics. (Hypothesis 3)

The appraisal of existing reports differs between stakeholder groups.

(Hypothesis 4)

Report-related factors. Most reports are published annually (PricewaterhouseCoopers, 2007). This was favored by $70 \%$ of 2,279 global SRep readers (Bartels et al., 2008) and 50\% of 115 German report readers (Clausen et al., 2001).

Given that most evidence indicates a preference for an annual reporting cycle, our fifth hypothesis is as follows:

Readers are interested in up-to-date information.

(Hypothesis 5)

Around $18 \%$ of companies in the forestry sector provided third party audits (PricewaterhouseCoopers, 2007), with higher levels found in companies operating within the EU (Petereit, 2008).

Despite calls for the forestry sector to consult stakeholders (Kolk et al., 2002), there is a paucity of research into the perspectives of non-managerial stakeholders regarding SR verification and credibilityenhancing techniques. Two surveys found that readers considered audited reports based on standard reporting guidelines being more trustworthy and discussed the factors which constituted a credible report (PKK, 2005;
Bartels et al., 2008). Professional auditing was assessed by English-speaking report readers as contributing the most to a report's credibility (PKK, 2005). A desire of stakeholders to play a greater role in verifying SReps has also been identified (Bartels et al., 2008).

On the basis of the broad findings outlined above, two further hypotheses are as follows:

External verification is seen as an important structural component of SR.

(Hypothesis 6)

Individual stakeholder groups prefer different verification systems.

(Hypothesis 7)

Sixty per cent of 495 SRep readers worldwide disliked reports longer than 50 pages (PKK, 2005; Steinert, 2005), with the majority of German readers preferring a report shorter than 30 pages (Clausen et al., 2001). Two-thirds of report readers said they spent less than 30 min reading a report (PKK, 2005), although a longer reading time of 1.5-2 $\mathrm{h}$ was found in a survey of German readers (Clausen et al., 2001).

In line with the comparatively broad consensus among previous studies, a hypothesis concerning the optimum length of a report is:

Readers prefer short reports.

(Hypothesis 8)

O'Dwyer et al. (2005) state that (printed or printable) stand-alone reports are favored over the dissemination of content via websites. KPMG (2008) found a similar preference for the use of stand-alone reports over the dissemination of contents through webpages. In the early 2000 s, online SR appeared to be growing in popularity for various cost and flexibility reasons. It was said to allow companies to tailor their reports to different stakeholder groups (ACCA, 2004) and allow publishers to print a short summary report, thereby meeting reader requirements for shorter reports while still providing comprehensive information online (Gebauer et al., 2007). Parviainen (2008) found that Finnish communication advisors considered internetbased communication to be the main tool for spreading forest sustainability information. However, since the mid-2000s, demand for innovative electronic reporting seems to have fallen while demand for fixed reporting formats, print or digital documents, has increased (PKK, 2005; Bartels et al., 2008).

On the basis of these findings, the last hypothesis is:

Currently, printed reports best meet stakeholder expectations.

As design, layout issues and language style are discussed only in a subordinate way in existing literature, they are not included in the present study. 


\section{MATERIALS AND METHODS}

\subsection{Organization of the forest sector in Germany}

Germany is politically divided into 16 provinces, of which 13 have a relevant forested area. There are three main ownership types: privately owned forests, forests which are under the control of municipalities or other public bodies (e.g. churches) and state forests. The latter are under the control of the state parliaments. The form of these state forest enterprises varies widely. Basically all state forest enterprises are dedicated to a multipurpose forestry, however, locally the emphasis on different basic forest functions (production, protection, recreation) can vary tremendously. Due to the high density of population in Germany the public interest in forest and its different functions is high. Related to this, there is a basic expectation that there is meaningful reporting on different aspects related to forest management. Related to the regional structure of forestry, the reports discussed subsequently are primarily of regional interest.

\subsection{Case study organizations and reports}

Baden-Württemberg (BW) is a highly populated state in Germany with a forest cover of about $40 \%$. Approximately $25 \%$ of the forest land is state forest. The state forest administration manages about 330,000 ha of state forest land. Based on the Forest Act, all forest functions (production, protection, and recreation) have to be integrated equally and to the highest possible standard. The importance of the individual functions varies - depending on the spatial attributes of the individual forest area - but notably there is no preeminent function.

Forest coverage in Schleswig-Holstein (SH) is about $10 \%$ and therefore rather low. Approximately one third of the forest land is owned by the state of $\mathrm{SH}$. Due to the low forest cover the importance of recreational use is much higher than in other regions; nevertheless, production and protection functions are also important.

The most relevant information about the two reports is presented in table 3. An in-depth analysis of the contents of the respective reports can be found in Howard (2010).

\subsection{Methods}

Survey on perceptions of target readers. The survey was designed as a so-called "independent evaluation" (Rossi et al., 2004). This implies that the research questions were designed by scientists and experts external to the forest administration in BW without participation of members of the future respondent groups. The questionnaire content and design was based on a former study on Global Reporting Guidelines (GRI) reporting (Hartebrodt et al., 2009a; Hartebrodt et al., 2009b), where more detailed information about the process of the study design is provided.

Readers of the 2007 Jahresbilanz (MLR, 2008) (annual balance) and the 2008 Geschäftsbericht (business report) (SHLF, 2009) from the state forest enterprises of BW and $\mathrm{SH}$ respectively were surveyed to identify their expectations regarding a state forestry report. The survey was conducted via a questionnaire included as a supplement to the above reports.

The recipients were requested to indicate their level of agreement or disagreement with $51^{2}$ statements (closed questions) in three areas:

- characteristics of a good report,

- satisfaction with the current report,

- topics which should be included in a report.

In most cases, responses were marked on a four point Likert scale (Likert, 1932) with a "don't know" option included for all questions. The questionnaire could be completed online or manually using the supplied questionnaire sheet.

After a pre-test of the questionnaire, seven different stakeholder groups were identified based on an earlier study indicating the target audiences of forestry reports in the German-speaking region (Hartebrodt et al., 2009a; Hartebrodt et al., 2009b). Within each stakeholder group, participants were randomly selected from a database maintained by the Forest Research Institute of Baden-Württemberg. This database included all recipients (about $80 \%$ ) and additionally about 500 randomly selected individuals. In total, 3,470 people received the questionnaire via postal mail in November 2008. Reminders were sent by email with an attached PDF version of the report in January and May 2009. The questionnaires were sent out to all 600 recipients of the printed SH state forestry 2008 business report in January 2010. No reminder was sent.

Statistical method. The responses to the individual questions must be seen as Likert items. Nevertheless, the response variables were symmetric in nature (strongly agree, widely agree, widely disagree, strongly disagree) and it must be assumed that these variables are on an ordinal scale (Jamieson, 2004). Notwithstanding the fact that parametric tests like ANOVA or F-Testing have been found to be very robust in terms of interval issues (comp. Glass et al., 1972), most authors recommend the use of nonparametric tests (e.g. Jamieson, 2004; Carifio \& Perla, 2007; Hollingsworth et al., 2011). Among others (chi-

\footnotetext{
${ }^{2} 55$ questions were asked in the BW questionnaire, as the Ministry added four more questions of special interest in BW.
} 
Table 3. Characteristics of the case study reports - Caractéristiques des rapports d'études de cas.

\begin{tabular}{|c|c|c|}
\hline Criterion & $\begin{array}{l}\text { Landesforstverwaltung Baden- } \\
\text { Württemberg }\end{array}$ & $\begin{array}{l}\text { Schleswig-Holsteinische } \\
\text { Landesforsten }\end{array}$ \\
\hline Type of report & Annual Balance & Business Report \\
\hline Editorial process & \multicolumn{2}{|c|}{$\begin{array}{l}\text { Contents are written by the individual departments of the state forest enterprise } \\
\text { Layout and design are outsourced to a graphic design enterprise }\end{array}$} \\
\hline Length & $36 \mathrm{pp}$ & $74 \mathrm{pp}$ \\
\hline Focus & $\begin{array}{l}27 \mathrm{pp} \text { narrative description of a wide } \\
\text { range of topics, } 3 \text { pp graphs and tables, } \\
6 \mathrm{pp} \text { others }\end{array}$ & $\begin{array}{l}34 \mathrm{pp} \text { narrative description of a wide } \\
\text { range of topics, } 20 \mathrm{pp} \text { business report } \\
\text { according to commercial code, } 10 \mathrm{pp} \\
\text { report on social services, } 9 \mathrm{pp} \text { others }\end{array}$ \\
\hline $\begin{array}{l}\text { Topics, structure of the report (pages } \\
\text { with }>80 \text { photographs are not counted) }\end{array}$ & $\begin{array}{l}\text { Preface }(1 \mathrm{p}) \text {, Summary of the past } \\
\text { financial year }(2 \mathrm{pp}) \text {, Report about } \\
\text { the State Forest Enterprise ( } 4 \mathrm{pp}) \text {, } \\
\text { Evaluation of the reorganisation of the } \\
\text { forest administration ( } 4 \mathrm{pp}) \text {, Climate } \\
\text { change }(4 \mathrm{pp}) \text {, Production of fuel wood } \\
(4 \mathrm{pp}) \text {, Education of forest workers } \\
(2 \mathrm{pp}) \text {, Certification of Forest pedagogy } \\
(2 \mathrm{pp}) \text {, Miscellaneous ( } 4 \mathrm{pp}) \text {, Figures } \\
\text { and Tables }(6 \mathrm{pp})\end{array}$ & $\begin{array}{l}\text { Preface }(4 \mathrm{pp}) \text {, Editorial (6 pp), } \\
\text { Timber production, Hunting, Services, } \\
\text { real estate management }(1 \mathrm{p} \mathrm{each}) \text {, } \\
\text { Activities of the forest rangers }(2 \mathrm{pp}) \text {, } \\
\text { Education forest }(2 \mathrm{pp}) \text {, Forest training } \\
\text { camps }(2 \mathrm{pp}) \text {, Silviculture }(2 \mathrm{pp}) \text {, } \\
\text { Certification }(1 \mathrm{p}) \text {, Afforestation }(1 \mathrm{p}) \text {, } \\
\text { Forest biodiversity issues }(2 \mathrm{p}) \text {, Strategy } \\
\text { (Sustainability Balanced Scorecard) } \\
(3 \mathrm{pp}), \text { Business report in a narrower } \\
\text { sense }(5 \mathrm{pp}) \text {, Risk management (2 pp), } \\
\text { Tables (4 pp), Accountant's report } \\
(2 \mathrm{pp}), \text { Special report on ecosystem } \\
\text { services (10 pp) }\end{array}$ \\
\hline Share of photographs & Approx. $40 \%$ & Approx. $30 \%$ \\
\hline Actuality & $\begin{array}{l}\text { Issued annually, approx. } 9 \text { months after } \\
\text { the end of the business year }\end{array}$ & $\begin{array}{l}\text { Issued annually, approx. } 10 \text { months } \\
\text { after the end of the business year }\end{array}$ \\
\hline Verification & None & $\begin{array}{l}\text { Third party verification of the financial } \\
\text { data. SBSC comparison between goals } \\
\text { and topical data related to the most } \\
\text { important sustainability goals given }\end{array}$ \\
\hline
\end{tabular}

squared, Spearman's Rho), the Mann-Whitney U-Test is a frequently applied and appropriate test (Mann \& Whitney, 1947). The individual stakeholder groups were seen as independent substrata (comp. Sheskin, 2000) and pairwise tests were carried out between all groups included in the study. Consequently, the findings about statistically significant differences are based on the rank orders of the responses (according to the Mann-Whitney U Test), not on mean values, etc. For the interpretation of the results it is important to mention that the critical values depend strongly on the number of cases in both groups. Thus smaller groups are less likely to be seen as statistically different.

\section{RESULTS}

\subsection{Preface}

As the institutions required a five-year period of confidentiality in regard to the results, it was necessary to postpone the publication until after the year 2015.

Hereafter, the results for all stakeholder groups with more than 10 questionnaires completed or subpopulations in which more than $10 \%$ of the total population completed questionnaires are reported. To enhance readability, the means of the coded Likert Scales are additionally partially presented in order to avoid the extensive depiction of frequency distributions for all individual questions and groups. In this case, code 4 represents absolute agreement to a statement, whereas code 1 indicates absolute disagreement. Averages above 2.5 are seen as an indicator for agreement; for averages below 1.5 it is assumed that the respondents expressed a basic disagreement with the statement. In between these thresholds, a more or less neutral position is assumed.

The levels of significance in all tables and figures are indicated as follows: in the case that statistically significant differences exist between two stakeholder groups, the respective groups are marked with the 
same character. Lower case characters indicate a $5 \%$ significance level; capitals show a $1 \%$ significance level.

\subsection{General findings}

The response rate was low (Table 4). The differences between the groups, which can be seen as meaningful in Baden-Württemberg only, show that the interest and willingness to exert their influence by participating was highest in the group of stakeholders who classified themselves as members of environmental and nature protection groups (environmentalists) or other forest owners. Due to the limited number of responses, the results gathered in $\mathrm{SH}$ can only be used to assess regional differences.

\subsection{Satisfaction with current reports}

The majority of respondents agreed with the statement "I'm satisfied / very satisfied with the annual balance of the State Forest Enterprise (BW) / the business report (SH)": 86.6\% from BW (2007 Annual Balance) and $86.9 \%$ from SH (2008 Business Report). More readers in $\mathrm{SH}(39.1 \%)$ than in BW $(21.5 \%)$ said that they were very satisfied with their report. Table 5 shows the level of overall satisfaction. The environmentalist stakeholder group was the most unsatisfied report reader group.

\subsection{Recipient-related factors}

Credibility. The perceived credibility of the reports is high. Except for the group of environmentalists in $\mathrm{BW}$, at least three-quarters of the readers assessed the credibility of the report as high or very high. Nevertheless, the proportion of respondents who had at least slight doubts in this regard was higher than for other issues presented in the paper (Table 6).

General interest. Most of the readers confirmed that they were the "right" recipient and that they were interested in the reports. The share of respondents who denied this statement was low $(<10 \%)$ in all stakeholder groups (Table 7).

Characteristics of a high quality report. The ranking of criteria which are deemed as being important to the quality of a report can be seen as a substitute for the normative setting of a respondent. Thus, respondents were queried about the importance of seven report characteristics with results shown in table 8 with the median and mean level of importance for each characteristic. The most important characteristics were credibility, how up-to-date the report and its contents were, and for some groups, a balanced depiction of the three sustainability pillars. Design and publishing aspects were considered less important.

Scope of report. A forest report issued by a public body can deal with different aspects of forestry. Insights into the most relevant subjects are of special interest. The most relevant result is that interests vary widely between different groups of readers. Groups are, on average, mostly interested in the activities of the forest administration and forestry of all property types (avg. groups 3.1). The management of state forests and a report about forests in general seemed to be less interesting for readers (avg. groups 2.9, 2.8). Differences between stakeholder groups are obvious and partially significant (Table 9).

Adequate depiction of different dimensions. One question focused on balance in the reports with respect to the three (sustainability) pillars. Most groups were

Table 4. Number of questionnaires distributed and received in Baden-Württemberg and Schleswig-Holstein - Nombre de questionnaires distribués et reçus dans le Baden-Württemberg et le Schleswig-Holstein.

\begin{tabular}{|c|c|c|c|c|}
\hline \multirow[t]{2}{*}{ Stakeholder group } & \multicolumn{2}{|c|}{ Baden-Württemberg } & \multicolumn{2}{|c|}{ Schleswig-Holstein } \\
\hline & Sent & Received & Sent & Received \\
\hline Forestry administration staff & 2,000 & $59(3 \%)$ & Not known & 3 \\
\hline Other forest management & 30 & $2(7 \%)$ & Not known & 7 \\
\hline Timber processing and manufacturing industry & 200 & $12(6 \%)$ & Not known & 4 \\
\hline Environment and nature protection & 30 & $4(13 \%)$ & Not known & 2 \\
\hline Political decision makers & 60 & $5(8 \%)$ & Not known & 0 \\
\hline Forest owners (communal and private) & 1,000 & $124(12 \%)$ & Not known & 0 \\
\hline Press & 50 & $1(2 \%)$ & Not known & 0 \\
\hline Other & 100 & $18(18 \%)$ & Not known & 9 \\
\hline Total & 3,470 & $225(6 \%)$ & 600 & $25(4 \%)$ \\
\hline
\end{tabular}


Table 5. Levels of overall satisfaction with case study reporting in different stakeholder groups - Les niveaux de satisfaction globale avec l'étude de cas de rapports dans les différents groupes de participants.

\begin{tabular}{|c|c|c|c|c|c|}
\hline \multirow[t]{2}{*}{ Stakeholder group } & \multicolumn{5}{|c|}{ Statement: I'm satisfied with the report (\%) } \\
\hline & Disagree absolutely & Disagree widely & Agree widely & Agree absolutely & Don't know \\
\hline Employees $(\mathrm{BW})^{\mathrm{A}}$ & 5.1 & 10.2 & 61.0 & 22.0 & 1.7 \\
\hline Timber industry (BW) & 0.0 & 0.0 & 70.0 & 30.0 & 0.0 \\
\hline Forest owners (BW) & 0.0 & 4.0 & 75.8 & 17.7 & 2.4 \\
\hline Environmentalists $(\mathrm{BW})^{\mathrm{A}}$ & 0.0 & 50.0 & 50.0 & 0.0 & 0.0 \\
\hline Average BW (all groups) & 1.8 & 8.1 & 65.1 & 21.5 & 1.8 \\
\hline Average SH (all groups) & 8.7 & 4.3 & 47.8 & 39.1 & 0.0 \\
\hline
\end{tabular}

Groups that are marked with characters show statistically significant differences. Capitals show differences on the $1 \%$ level - les groupes qui sont accompagnés de lettres ont des diffférences statistiquement significatives. Les majuscules indiquent des différences selon un seuil de $1 \%$; BW: Baden-Württemberg; SH: Schleswig-Holstein.

Table 6. Appraisal of credibility by different stakeholder groups - Évaluation de la crédibilité dans les différents groupes de participants.

\begin{tabular}{|c|c|c|c|c|c|}
\hline \multirow[t]{2}{*}{ Stakeholder group } & \multicolumn{5}{|c|}{ Statement: I consider the information and data in the report to be credible (\%) } \\
\hline & Disagree absolutely & Disagree widely & Agree widely & Agree absolutely & Don't know \\
\hline Employees (BW) & 3.5 & 5.3 & 57.9 & 29.8 & 3.5 \\
\hline Timber Industry (BW) & 0.0 & 18.2 & 54.5 & 27.3 & 0.0 \\
\hline Forest Owners (BW) & 0.0 & 5.0 & 60.5 & 30.3 & 4.2 \\
\hline Environmentalists (BW) & 0.0 & 50.0 & 25.0 & 25.0 & 0.0 \\
\hline All (BW) & 0.9 & 7.7 & 57.7 & 30.0 & 3.6 \\
\hline All (SH) & 4.3 & 21.7 & 52.2 & 21.7 & 0.0 \\
\hline
\end{tabular}

BW: Baden-Württemberg; SH: Schleswig-Holstein.

Table 7. Interest of readers and self-classification as target reader - Intérêt des lecteurs et auto-classification comme lecteur cible.

\begin{tabular}{llllll}
\hline \multirow{2}{*}{ Stakeholder group } & \multicolumn{4}{l}{ Statement: I'm interested in the report; I'm the right recipient $(\%)$} \\
\cline { 2 - 6 } & Disagree absolutely & Disagree widely & Agree widely & Agree absolutely & Don't know \\
\hline Employees (BW) & 1.9 & 5.6 & 42.6 & 50.0 & 0.0 \\
Timber Industry (BW) & 0.0 & 0.0 & 33.3 & 58.3 & 8.3 \\
\hline Forest Owners (BW) & 0.0 & 4.0 & 75.8 & 17.7 & 2.4 \\
Environmentalists (BW) & 0.0 & 0.0 & 33.3 & 66.7 & 0.0 \\
All (BW) & 0.9 & 5.6 & 50.0 & 40.3 & 3.2 \\
All (SH) & 4.3 & 4.3 & 39.1 & 52.2 & 0.0 \\
\hline
\end{tabular}

Legend - légende: see table 5 - voir tableau 5.

satisfied, but not very satisfied. The environmentalists expressed the most critical position (Table 10), however no significant distinctions were observed.

Contents. Thematic interests are seen as being strongly related to the individual and therefore also recipient- related. The level of interest in topics varies widely. In figure 2, the varying patterns in interest levels relating to different topics show that the differences between the various stakeholder group evaluations can be tremendous in some respects but not for every topic. 


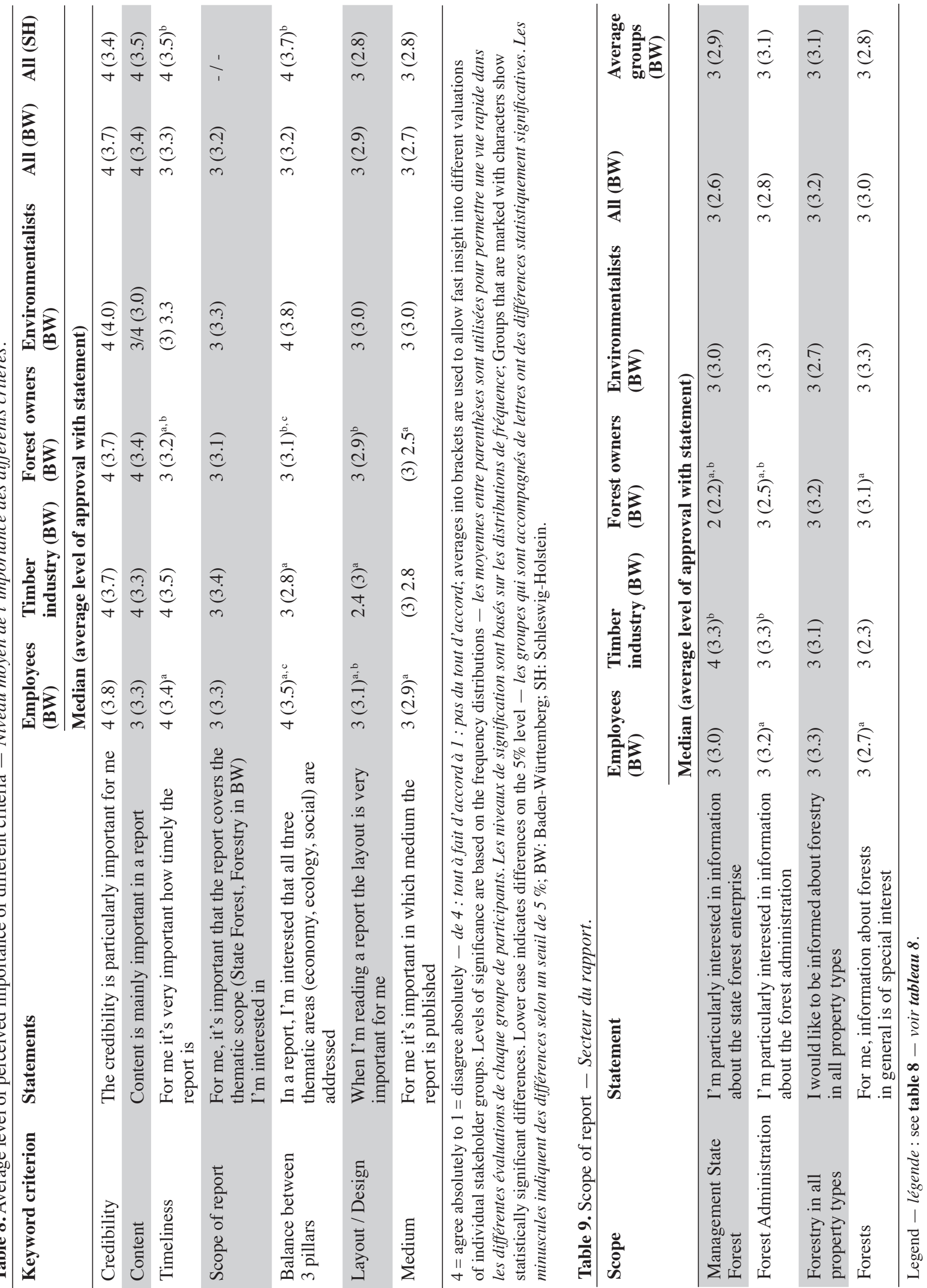


Table 10. Adequacy of the three pillars (economy, ecology, social aspects) - L'équilibre entre les trois piliers (économie, écologie, aspects sociaux).

\begin{tabular}{lcllll}
\hline \multirow{2}{*}{ Stakeholder group } & \multicolumn{5}{l}{ Statement: I'm satisfied with the representation of the three pillars $(\%)$} \\
\cline { 2 - 6 } & Disagree absolutely & Disagree widely & Agree widely & Agree absolutely & Don't know \\
\hline Employees (BW) & 0.0 & 17.5 & 49.2 & 33.3 & 0.0 \\
Timber industry (BW) & 10.0 & 20.0 & 60.0 & 10.0 & 0.0 \\
Forest owners (BW) & 0.8 & 12.4 & 68.6 & 15.7 & 2.5 \\
Environmentalists (BW) & 0.0 & 33.3 & 67.7 & 0.0 & 0.0 \\
All (BW) & 0.9 & 15.4 & 59.7 & 21.7 & 2.2 \\
All (SH) & 4.4 & 17.4 & 56.5 & 21.7 & 0.0 \\
\hline
\end{tabular}

BW: Baden-Württemberg; SH: Schleswig-Holstein.

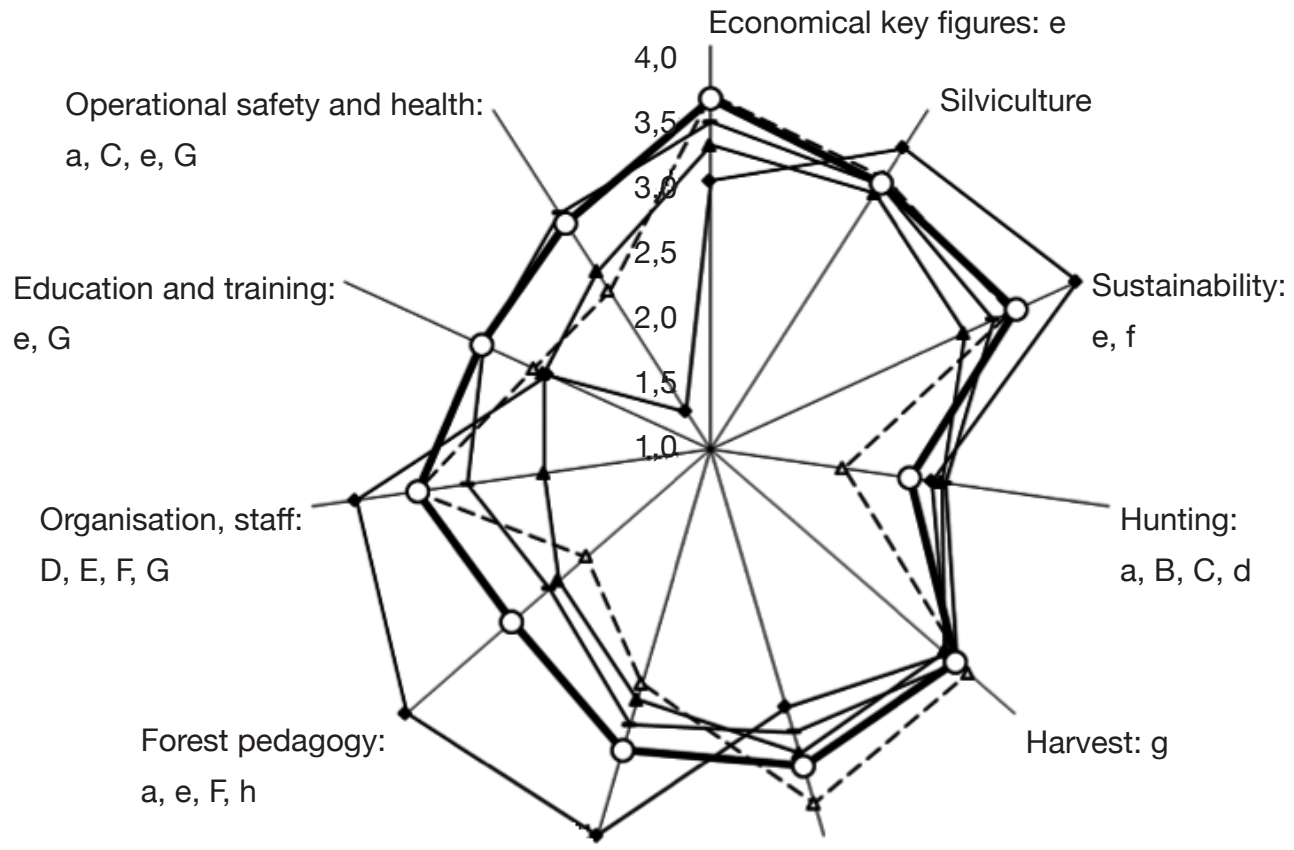

Nature protection: e, g, F, h

Timbersales: B, d

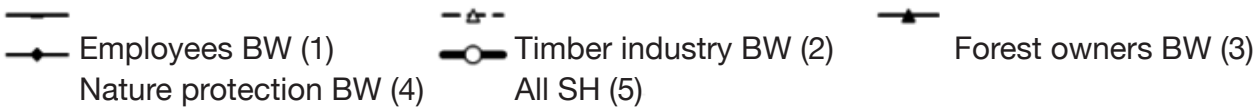

Figure 2. Evaluation of interest in different topics (4 = very high; 1 = very low) - Évaluation de l'intérêt pour des sujets différents $(4=$ très élevé ; 1 = très faible $)$.

Statistically significant differences between groups - différences statistiquement significatives entre les groupes: (1) \& (2): a; (1) \& (5): B, b; (2) \& (5): C; (2) \& (3): D, d; (3) \& (5): E, e; (4) \& (3): F, f; (1) \& (3); G, g; (3) \& (4): H; lower case characters indicate significance on the $5 \%$ level, capitals significance on the $1 \%$ level - les minuscules indiquent des différences significatives au seuil de $5 \%$, les majusucules, au seuil de $1 \%$.

Whereas silviculture, sustainability, hunting, harvest, and timber sales were of equal interest to most groups, differences with regard to other topics were more substantial. In this regard, differences between the case study regions also became visible. Logging, timber sales, and key economic figures were of greater interest to the timber industry group, while forestry education and hunting were of less interest. Employees focus on occupational safety and health and forest pedagogy and training. Forest owners are less interested in organization and staff issues. It was especially noticeable that the group of respondents who 
had characterized themselves as "environmentalists" had a unique set of interests.

\subsection{Report-related factors}

Verification techniques. Report credibility was important to readers in both surveys. Readers were asked whether they considered reports to be more credible when they utilize four different verification techniques, as shown in table 11. A majority of readers agreed or strongly agreed that using standardized contents and comparing planned and actual progress enhance the credibility of a report.

Readers in BW were more ambivalent about the effect of auditing. Stakeholders from the timber industry and state forestry employees were most sceptical regarding the effect of auditing on report credibility. Involving stakeholders in the report development process was not considered by most readers to be an effective means of enhancing credibility. An exception here was the environmentalists who also preferred more certification and participation than other stakeholder groups.

Timeliness. The results related to the issue of timeliness are ambiguous and differ widely. A minority stated that the issuing time, which is three-quarters of a year after the end of the preceding business year, is right. However, looking at the average of all stakeholder groups in both case study regions, almost the same proportions stated that a report should be published either earlier or later (Table 12).

Length of reports. The optimum length of reports is often a matter of discussion. The length of the two case study reports also differed (BW 36 pages; SH 74 pages). Despite this difference, the preference of the readers was broadly similar (Table 13). The majority was satisfied with the length; about a third would prefer shorter reports.

Medium. There is an ongoing discussion as to whether the web can replace printed reports. However, all groups indicated a preference for printed reports. Internet is not seen as a relevant option and even a combination of print and web-based information was mostly evaluated negatively (Table 14).

\section{DISCUSSION}

This paper sought to identify the expectations of different stakeholder groups regarding German state forestry reports. Unfortunately, the low questionnaire response rate prevented a data analysis of all stakeholder groups. At first sight, the low response

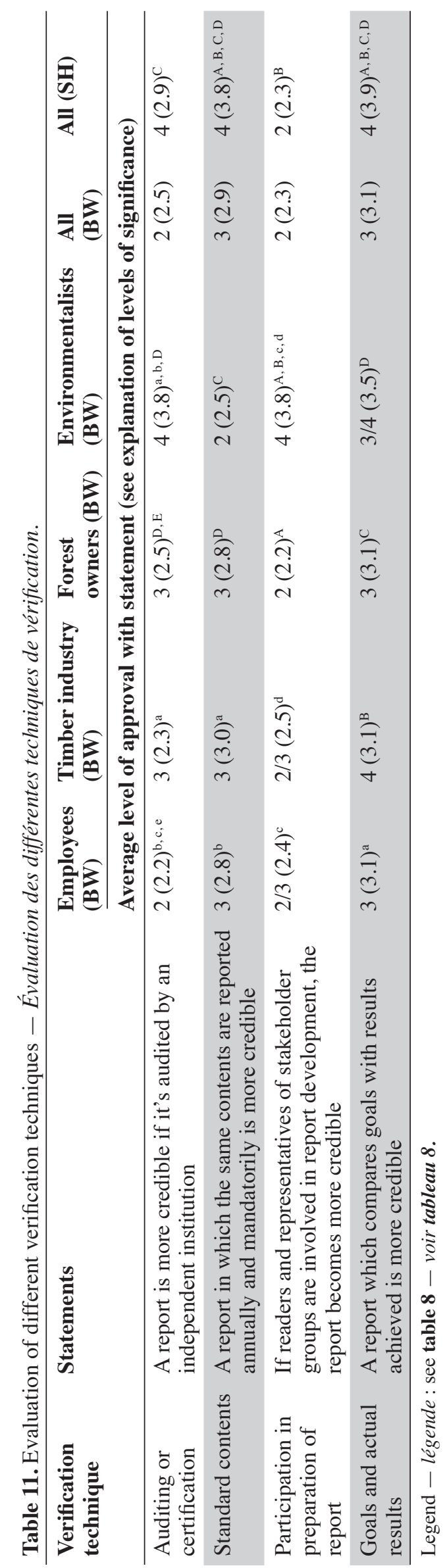


Table 12. Timeliness - Actualité.

\begin{tabular}{lcll}
\hline Stakeholder group & Right $(\%)$ & Earlier (data partial, preliminary) $(\%)$ & Later (all data final) $(\%)$ \\
\hline Employees (BW) ${ }^{\text {a, C }}$ & 41.1 & 42.9 & 16.1 \\
Timber industry (BW) $^{\text {a, b }}$ & 9.1 & 45.5 & 45.5 \\
Forest owners (BW) $^{\text {b, D }}$ & 56.8 & 16.1 & 27.1 \\
Environmentalists (BW) & 0.00 & 33.3 & 66.7 \\
All (BW) & 48.6 & 25.9 & 25.5 \\
All (SH) ${ }^{\text {, D }}$ & 26.1 & 39.1 & 34.8 \\
\hline
\end{tabular}

Groups that are marked with characters show statistically significant differences. Lower case indicates differences on the $5 \%$ level, capitals show differences on the $1 \%$ level - les groupes qui sont accompagnés de lettres ont des différences statistiquement significatives. Les minuscules indiquent des différences selon un seuil de $5 \%$, les majuscules, selon un seuil de $1 \%$; BW: BadenWürttemberg; SH: Schleswig-Holstein.

Table 13. Appraisal of report length (\%) - Appréciation de la longueur du rapport (\%).

\begin{tabular}{llll}
\hline Stakeholder group & Right & Shorter & Longer \\
\hline Employees (BW) & 63.2 & 28.1 & 8.8 \\
Timber industry (BW) & 54.5 & 36.4 & 9.1 \\
Forest owners (BW) & 51.7 & 48.3 & 0.0 \\
Environmentalists (BW) & 66.7 & 33.3 & 0.0 \\
All (BW) & 54.8 & 40.3 & 5.0 \\
All (SH) & 60.9 & 39.1 & 0.0 \\
\hline
\end{tabular}

BW: Baden-Württemberg; SH: Schleswig-Holstein.

Table 14. Preferred media - Supports préférés.

\begin{tabular}{llll}
\hline Stakeholder group & Print & Internet & $\begin{array}{l}\text { Internet } \\
\text { + Print }\end{array}$ \\
\hline Employees (BW) & $4(3.5)$ & $1(1.7)^{\mathrm{A}}$ & $2(2.4)^{\mathrm{A}}$ \\
Timber industry (BW) & $4(3.4)$ & $2(2.2)$ & $2(2.1)^{\mathrm{B}}$ \\
\hline $\begin{array}{l}\text { Forest owners (BW) } \\
4(3.4)\end{array}$ & $2(2.0)^{\mathrm{A}, \mathrm{B}}$ & $4(3.0)^{\mathrm{A}, \mathrm{B}, \mathrm{C}}$ \\
$\begin{array}{l}\text { Environmentalists } \\
(\mathrm{BW})\end{array}$ & $4(3.5)$ & $2(1.3)$ & $\begin{array}{l}\text { Even } \\
\text { distribution } \\
(2.50)\end{array}$ \\
All (BW) & $4(3.4)$ & $2(1.9)$ & $2(2.7)$ \\
All (SH) & $4(3.4)$ & $1(1.6)^{\mathrm{B}}$ & $2(2.2)^{\mathrm{C}}$ \\
\hline
\end{tabular}

Legend - légende: see table 12 - voir tableau 12.

rate might be surprising; however, extensive literature about response fatigue provides various explanations in this regard.

Applying the planned behavior theory, Bosnjak et al. (2005) found that four components influence willingness to participate. These are:

- attitude towards participation,

- perceived normative pressure to participate,
- perceived control,

- the level of moral obligation.

At least the last three factors can almost be excluded when carrying out a survey on reports. The issue of whether the content of a survey is of importance or high salience is frequently discussed (Sheehan, 2001; Porter et al., 2004; Fan \& Yan, 2010). Again, a lowering effect must be assumed for the sort and topic of questions raised in that survey. Although there is mixed experience (Sheehan, 2001), the length of a survey can also have the effect of reducing the response rate. Sheehan (2001) provides evidence that the response rates in email surveys decreased notably in the period between 1986 and 2000. Even in the last years of the 1990s, a response rate of less than $30 \%$ was achieved. Given the steadily increasing number of surveys in the past two decades, it can be assumed that response rates may now be much lower. The timing of the survey in SH may additionally have had an effect given that the questionnaire was sent out during the Christmas vacation period and only a relatively short amount of time was allowed for its completion.

All in all, there are more factors that could potentially explain the low response rate achieved, than factors which could support high response rates in such surveys.

Despite this limitation, which mainly impacted the statistical analysis and inhibited a comparison between some stakeholder groups, detailed insights and testing of the hypotheses remained possible. However, it may have decreased the proportion of statistically significant differences, due to the mathematical realities of the statistical test applied (MWU).

As the case study reports have only a partial SR structure, this overall evaluation can only give some hint as to the question of transferability of SR to the German forest sector. Together with the findings related to the individual structural components of 
SR discussed below, we can nevertheless confirm hypothesis 1 (SR with its structural components [e.g. stakeholder involvement, multidimensionality, and use of verification techniques] is basically transferable to the German forest sector). However, the fact that semitraditional formats were positively evaluated means that SR has only limited potential to improve reader satisfaction.

The low response rate can be seen as an indicator of the target readers' low interest in and potential underlying scepticism towards reporting. Some degree of dissatisfaction can be assumed but not proven. The respondents did not perceive any relevant distinctions in the intensity of the reports in terms of coverage of the three pillars of sustainability. The inclusion of different topics can help to cover the requirement from different readers for broad information. Thus, hypothesis 2 (Stakeholders dislike current reporting and see inadequacies in reporting as well as imbalances across different dimensions) can be neither proven nor refuted.

The hypothesis 3 (Stakeholder groups are interested in different topics) proved to be true. Despite the fact that we found only a few statistically significant differences related to the overall scope of the report, it can be shown that the perception of individual topics differs widely. Here, the highest share of statistically significant and, moreover, highly significant differences were found. Thus, existing knowledge that target group oriented reports are basically beneficial can also be seen in various forest stakeholder groups. Previous findings of Hartebrodt et al. (2009b), which indicated that forestry reports in the German-speaking region were most often far-reaching and therefore addressing employee and sector members' interests but not wider societal interests, were supported. The lower level of current readers' interest in social topics and the lower satisfaction with the report's contents shown by the environmental and nature protection stakeholder groups - although this group only had four respondents - also lends some support to this finding.

Almost $90 \%$ of readers were satisfied or very satisfied with their report. This indicates a strong alignment between the two reports and their readers' overall expectations. This satisfaction level is higher than was found in other surveys and showed almost no statistical differences between stakeholder groups. Consequently, we basically refute hypothesis 4 (The appraisal of existing reports differs between stakeholder groups). Nevertheless, mention should be made of the fact that some single stakeholder groups indicated a different perception.

Both case study reports are disseminated approximately three-quarters of a year after the reporting period. The reports' publishing dates did not meet the expectations of all reader groups.
Unfortunately, the results do not provide any indication as to preferred publishing dates as the unsatisfied respondents were evenly split between preferring an earlier report with preliminary data or a later report with comprehensive, accurate data. Readers of German state forestry reports want accurate and timely information and not all stakeholder groups are satisfied with current deliverables. Thus, hypothesis 5 (Readers are interested in up-to-date information) can be neither proven nor refuted.

The credibility of a report is very important to readers. Two verification techniques were widely accepted. The application of reporting standards (e.g . GRI-Standards, GRI, 2006) and a type of reporting in which the results achieved can be compared with the underlying objectives of the forest enterprise. Third party auditing, which is the most common verification technique used in the German state forestry sector, was evaluated more ambivalently by stakeholders from the timber industry and more sceptically by employees. In $\mathrm{SH}$, despite there being a similar proportion of timber industry and employees stakeholders, it was viewed more positively. The participation of stakeholders in a report was not considered to enhance credibility, with forest owners holding a particularly negative view in this regard. As they made up 55\% of the survey respondents in $\mathrm{BW}$, their rejection of this technique possibly skewed the results given that greater levels of support for stakeholder participation have been found in other report reader surveys (Bartels et al., 2008). However, no forest owners were included in the SH dataset, so the influence of this stakeholder group cannot explain why this technique was also opposed in SH. Perhaps the small sample size plays a role here. These results are partly consistent with other surveys where readers also favored following reporting standards and comparing actual and planned progress as credibility enhancing techniques (Bartels et al., 2008). Support for stakeholder participation and auditing as found in other reader surveys (PKK, 2005) was only indicated by the small number of environmentalists. Counterintuitively, readers of the $\mathrm{SH}$ report - which included an independent financial audit and compared planned and actual progress - rated its credibility slightly less satisfactorily than readers of the BW report which had no credibility enhancing techniques. This may be because these public agencies build credibility in other ways such as through personal relationships. Report credibility appears very important to readers and the majority of German state forestry enterprises would have to introduce good governance and management techniques by following reporting standards and reporting progress against identified goals if they want to meet their stakeholders' expectations of a credible report. In summary, it is apparent that verification in general plays a substantial 
role for readers of forest reports. Thus, we confirm hypothesis 6 (External verification is seen as an important structural component of SR).

As verification techniques were a topic relating to which we found a relevant number of statistically significant differences between the groups, our hypothesis 7 (Individual stakeholder groups prefer different verification systems) was additionally proven to be true.

Recalling that the Baden-Württemberg report is 32 pages long and the $\mathrm{SH} 74$, it is surprising that a similar majority of readers in each survey considered that the reports were of an appropriate length. However, approximately $40 \%$ of readers in both surveys did want a shorter report. The comparable level of satisfaction with report length in this survey - despite one report being over twice as long as the other and longer than what readers in other surveys found satisfactory - may indicate that readers only read particular sections of the reports and hence do not consider the overall report length to be overly important. In the current survey, most readers said they spent between $5 \mathrm{~min}$ and $1 \mathrm{~h}$ reading their respective report, which confirms this theory. This concurs partially with findings in other surveys (Clausen et al., 2001) and best practice recommendations that report producers should ensure that their main messages can be read in $30 \mathrm{~min}$ (PKK, 2005). On this basis it can be concluded that hypothesis 8 (Readers prefer short reports) also applies to forest report readers.

Readers did not consider the report medium to be an important report characteristic. Nevertheless, there was a clear preference for a printed report over web-based reports as has been found in past studies. This preference is consistent with findings from other surveys of SRep readers, particularly in Germany (PKK, 2005; Steinert, 2005; Bartels et al., 2008). Hypothesis 9 (Currently, printed reports best meet stakeholder expectations) can therefore be confirmed.

\section{CONCLUSIONS}

This paper has highlighted what German forestry stakeholders expect of a state forestry report and reflected on four leading questions. As most of the hypotheses derived from general findings were proven to be true or could not be entirely refuted, one can state that forest readers are not very different from members of other sectors. Thus, when developing SR in the forest sector, overall findings and cross-sectoral guidelines can be used.

Our in-depth analysis of existing reports shows that despite some uncertainties arising from the fact that no full SR was assessed, there is a wide overlap between general findings on SR and our appraisal of the case study reports. From that, it follows that existing knowledge on reporting instruments and contents can and should be used when designing forest SReps.

Findings related to questions of how to deal with different stakeholder groups are twofold. Readers exhibited few significant differences in their expectations and were generally similarly satisfied with current reports. They expect reports to be credible, up-to-date, and to contain materially relevant information. The respondents stated that design issues are generally of minor importance (comp. Table 8); however, they clearly preferred short, printed reports which could be read in less than $1 \mathrm{~h}$. Therefore, there is no need to use systematically different reporting approaches to reach different stakeholder groups.

The use of verification techniques seems to be a requirement for future reporting. However, looking at contents and the question of which verification technique best meets stakeholder groups' expectations, different interests are revealed. In addition, reader groups show a visible connection to verification techniques they are used to or believe in. Readers are interested to comparable degrees in forestry topics but some topics of particular importance to specific stakeholder groups (e.g. "environmentalists") are not covered completely.

As different printed reports are probably not an option, additional communication instruments may be useful in addressing specific stakeholder interests. Nevertheless, the contention that differently tailored reports are essential to meet the needs of different stakeholder groups does not seem to completely apply to the German forestry sector.

Following on from the proven transferability of general findings and the only partial differences found between stakeholder groups, it is not too surprising that we found no indications of any strong regional differences.

Given the explorative nature of this research, there are a number of areas which could be investigated further. The survey has the common non-respondent problem that it reflects the opinions of readers who responded to the questionnaire and not all forestry stakeholders. To gain a more comprehensive forestry stakeholder perspective, a more extensive survey with more representative stakeholder groupings including current non-report readers would be needed. Selected forestry stakeholders could be interviewed directly. It would also be useful to ask readers about their satisfaction with reporting on environmental, social, and economic performance separately and to enquire if they read the entire report or only certain sections and how they use the featured information. The depiction of various aspects of sustainability appears important to readers suggesting there is stakeholder interest in SR. Without a doubt, whatever reporting 
instrument is used, its communicative effectiveness will be improved by regular consultation with stakeholders.

\section{Bibliography}

ACCA, 2004. Towards transparency: progress on global sustainability reporting 2004. London: Certified Accountants Educational Trust.

ACCSR, 2012. The State of CSR in Australia. Stakeholders as readers of sustainability reports. South Yarra, Australia: Australian Center for Corporate Social Responsibility.

Akzente Kommunikation und Beratung Gmbh und Institute 4 Sustainability, 2010. Stakeholder relationship management in Deutschland: Status Quo und Herausforderung - Eine Befragung. München, Deutschland; Berlin: Akzente Kommunikation und Beratung Gmbh.

Bartels W., Iansen-Rogers J. \& Kuszewski J., 2008. Count me in. The readers' take on sustainability reporting. KPMG International and Sustainability Ltd, https:// www.globalreporting.org/resourcelibrary/Count-MeIn-The-Readers-take-on-Sustainability-Reporting.pdf, (24/05/2011).

Bellantuono N., Pontrandolfo P. \& Scozzi B., 2016. Capturing the stakeholders' view in sustainability reporting: a novel approach. Sustainability, 8(4), 379.

Bentele G., Steinmann H. \& Zerfass A., 1996. Dialogorientierte Unternehmenskommunikation. Grundlagen, Praxiserfahrungen, Perspektiven. Berlin: Vistas.

Bosnjak M., Tuten T.L. \& Wittmann W.E., 2005. Unit (non) response in web-based access panel surveys: an extended planned-behaviour approach. Psychol. Marketing, 22(6), 480-505.

Bradford M., Earp J. \& Williams P., 2014. Sustainability reports: what do stakeholders really want? Manage. Accounting Q., 16(1), 13-18.

Carifio J. \& Perla R.J., 2007. Ten common misunderstandings, misconceptions, persistent myths and urban legends about likert scales and likert response formats and their antidotes. J. Soc. Sci., 3(3), 106-116.

Clausen J. et al., 2001. The INEM sustainability reporting guide. A manual on practical and convincing communication for future orientated companies. Hamburg, Germany: International Network for Environmental Management.

Clausen J. \& Loew T., 2005. Mehr Glaubwürdigkeit durch Testate? Internationale Analyse des Nutzens von Testaten in der Umwelt- und Nachhaltigkeitsberichterstattung. Endbericht des IÖW an das BMU. Hannover, Deutschland; Berlin: Institute for Ecological Economy Research (IÖW) GmbH.

Ernst \& Young LLP, 2016. Value of sustainability reporting. A study by EY and Boston College Center for Corporate Citizenship. Cleveland, USA: Ernst \& Young.
Evaluation Waldbericht Schweiz, 2005. https:/www.zhaw. ch/no_cache/de/forschung/personen-publikationenprojekte/detailansicht-projekt/projekt/257,(23/03/2016).

Fan W. \& Yan Z., 2010. Factors affecting response rates of the web survey: a systematic review. Comput. Hum. Behav., 26, 132-139.

Gebauer J., Hoffmann E. \& Westermann U., 2007. Sustainability reporting in Germany. Results and trends in the ranking 2007. Berlin: Institute for Ecological Economy Research (IÖW) $\mathrm{GmbH}$ and future e.V..

Gebauer J. et al., 2010. IÖW/future ranking of sustainability reports: results and trends. Berlin: Institute for Ecological Economy Research (IÖW) GmbH ; Münster, Germany: future e.V. - Verantwortung unternehmen.

Gebauer J., Hoffmann E. \& Westermann U., 2011. Anforderungen an die Nachhaltigkeitsberichterstattung: Kriterien und Bewertungsmethode im IÖW/futureRanking. Berlin: Institute for Ecological Economy Research (IÖW) GmbH ; Münster, Germany: future e.V. verantwortung unternehmen.

Gebauer J. \& Glahe J., 2011. Praxis der Nachhaltigkeitsberichterstattung in deutschen Großunternehmen. Befragungsergebnisse im Rahmen des IÖW/future-Rankings 2011. Berlin: Institute for Ecological Economy Research (IÖW) $\mathrm{GmbH}$.

Glass G.V., Peckham P.D. \& Sanders J.R., 1972. Consequences of failier to meet assumptions underlying the analyses of variance and covariance. Rev. Educ. Res., 42, 237-288.

Global Reporting Initiative, 2011. Sustainability reporting guidelines. Version 3.1.49. Amsterdam, The Netherlands: Global Reporting Initiative.

Greer J. \& Bruno K., 1996. Greenwash: the reality behind corporate environmentalism, third world network. New York, NY, USA: Apex Press.

GRI (Global Reporting Initiative), 2006. Sustainability reporting guidelines. Version 3.0. Amsterdam, The Netherlands: Global Reporting Initiative, https:/www. globalreporting.org/resourcelibrary/G3-Guidelines-InclTechnical-Protocol.pdf, (24/10/2012).

Gruda G., 2016. Costs of reporting, https://de.wikipedia.org/ wiki/Gesch\%C3\%A4ftsbericht, (03/01/2017).

Harmoni A., 2013.Stakeholder-based analysis of sustainability report: a case study on mining companies in Indonesia. In: Sari S., Gencer A.H. \& Sözen I., eds. Proceedings of the International Conference on Eurasian Economies 2013, 17-18 September 2013, St. Petersburg, Russia, 204-210.

Hartebrodt C., von Wedel K. \& Bitz S., 2009a. Forest enterprises' perceptions about multidimensional reportingsystems. In: Jöbstil H.A. \& Roder Ch., eds. Proceedings of the International Symposium, Managerial Economics and Accounting as an Evolving Paradigm of Forest Management, University of Applied Forest Sciences, Rottenburg, Germany. Vienna: BOKU-University of Natural Resources and Applied Life Sciences, $2^{\text {nd }}$ ed., 209-224. 
Hartebrodt C., von Wedel K., Bitz S. \&. Kenntner C., 2009b. Traditionelle und neue Berichtskonzepte in der Forst und Holzwirtschaft. J. For. Suisse, 160(2), 37-46.

Hollingsworth R.G., Collins T.P., Smith V.E. \& Nelson S.C., 2011. Simple statistics for correlation survey responses.

J. Extension, 49(5), 5ToT7

Howard K., 2010. Sustainability reporting in the German state forestry sector: the stakeholder perspective. Master thesis submitted in partial fulfilment of the requirements for the degree of Master of Science in Environmental Governance: University of Freiburg (Germany).

IÖW/future, 2009. IÖW/future Ranking 2009: sustainability reporting of German small and medium-sized enterprises. Berlin: Institute for Ecological Economy Research (IÖW) $\mathrm{GmbH}$; Münster, Germany: future e.V. - verantwortung unternehmen.

IÖW/future, 2012. IÖW/future-Ranking der Nachhaltigkeitsberichte deutscher KMU 2011: Ergebnisse und Trends. Berlin: Institute for Ecological Economy Research (IÖW) GmbH ; Münster, Germany: future e.V. - Verantwortung unternehmen

Jamieson S., 2004. Likert scales: how to (ab)use them. Med. Educ., 38, 1217-1218.

Kenk G., 1975. Konzeption einer Sozialbilanz 1975 der Landesforstverwaltung Baden-Württemberg. Allg. Forstz., 4, 86-90.

Kindler E., 2015. Analyse zur erweiterten Nachhaltigkeitsberichterstattung deutscher Länderforstbetriebe. Landbauforsch. Appl. Agric. For. Res., 65(2), 131-144.

Kolk A., 2004. A decade of sustainability reporting: developments and significance. Int. J. Environ. Sustainable Dev., 3(1), 51-64.

Kolk A., van der Veen M.L. \& Hay D.W., 2002. KPMG international survey of corporate sustainability reporting. Amsterdam, The Netherlands: KPMG Global Sustainability Services.

KPMG, 2008. KPMG International survey of corporate responsibility reporting 2008. KPMG.

Küpper H.-U., 2004. Controlling, Konzeption, Aufgaben, Instrumente. $4^{\text {th }}$ ed. Stuttgart, Deutschland: SchäfferPoeschel.

Likert R., 1932. A technique for the measurement of attitudes. Arch. Psychol., 140, 1-55.

Loew T., 2005. Ergebnisse der Stakeholderbefragung zum Nachhaltigkeitsbericht der WestLB AG. Berlin: Institute 4 Sustainability.

Mann H. \& Whitney D., 1947. On a test of whether one of two random variables is stochastically larger than the other. Ann. Math. Stat., 18, 50-60.

MLR (Ministerium Ländlicher Raum), 2008. Jahresbilanz 2007 - Rückblick für die Zukunft. Stuttgart, Deutschland: MLR.

O’Dwyer B., Unerman J. \& Hession E., 2005. User needs in sustainability reporting: perspectives of stakeholders in Ireland. Eur. Accounting Rev., 14(4), 759-787.
Parviainen J., 2008. The use and audiences of national forest sustainability reports. In: Proceedings of the Forest criteria and indicators analytical framework and report workshop, 19-21 May 2008, Joensuu, Finland.

Petereit A., 2008. Sustainability reporting of the forest and paper sector - Recommendations for improvements of corporate responsibility reports of forest and paper companies based on quality assessments. Master Thesis no.116: Southern Swedish Forest Research Centre, Uppsala (Sweden).

PKK (Pleon Kothes Klewes), 2005. Accounting for good: the global stakeholder reporting 2005. Bonn, Germany; Amsterdam, The Netherlands: Pleon Kohtes Klewes $\mathrm{GmbH}$ and Pleon b.v.

Porter S.R., Whitcomb M.E. \& Weitzer W.H., 2004. Multiple surveys of students and survey fatigue. New Directions Institutional Res., 121, 63-73

PricewaterhouseCoopers, 2007. Measuring up.Sustainability reporting in the forest, paper and packaging industry. Vancouver, Canada: PricewaterhouseCoopers.

Rossi P.H., Lipsey M.W., Freemann H.E. \& Howard E., 2004. Evaluation: a systematic approach. 7. Thousand Oaks, CA, USA; London; New Dehli: Sage.

Sheehan K.B., 2001. E-mail survey response rates: a review. J. Comput.-Mediated Commun., 6(2), doi:10.1111/j.1083-6101.2001.tb00117.x

Sheskin D., 2000. Handbook of parametric and nonparametric statistical procedures. $2^{\text {nd }}$ ed. Boca Raton, FL, USA: Chapman and Hall/CRC.

SHLF (Schleswig-holsteinische Landesforsten), 2009. Geschäftsbericht 2007, Wald für mehr. Neumünster, Deutschland: SHLF.

Steinert A., 2005. Print versus Internet in non-financial reporting. Bonn: Pleon Kohtes Klewes.

SustainAbility Ltd, 2006. Tomorrow's value: the global reporters 2006 survey of corporate sustainability reporting. $1^{\text {st }}$ ed. London; New York, USA: SustainAbility.

Thurm R., 2013. Reforming sustainability reporting: for and against. The Guardian, https://www.theguardian.com/ sustainable-business/reforming-sustainability-reportingpros-cons, (02/12/2016).

Tilt C.A., 2007. External stakeholders' perspectives on sustainability reporting. In: O'Dwyer B., Bebbington J. \& Unerman J., eds. Sustainability accounting and accountability. Oxon, UK: Routledge, 104-126.

Wendler L., 2015. Häufig viel zu kompliziert. Hamburger Abendblatt, http://www.abendblatt.de/wirtschaft/ article107052027/Geschaeftsberichte-haeufig-viel-zukompliziert.html (02/01/2017).

Wensen K.v., Broer W., Klein J. \& Knopf J., 2010. The state of play in sustainability reporting in the European Union. Berlin; Amsterdam, The Netherlands; CREM, Adelphi. 